\title{
Spatio-temporal structure of natural forest: A structural index approach
}

\author{
*M. Balanda ${ }^{1}$
}

${ }^{1}$ Technical university in Zvolen, Department of Silviculture, Faculty of Forestry, T. G. Masaryka 24, 96053 Zvolen, Slovak republic.E-mail:miroslav.balanda@tuzvo.sk

Abstract: Balanda, M. 2012: Spatio-temporal structure of natural forest: A structural index approach. - Beskydy, 5 (2): 163-172

The submitted paper deals with the analysis of stand structure of mixed species natural forest located in the Carpathians, Middle Europe. In order to evaluation of structural diversity we chose the combination of distance independent and nearestneighbor indices. Following structural indices were calculated: Shanon-Weaver index $(S-W)$, diameter differentiation index $(T d)$, Gigi coefficient $(G)$, mingling index $(D M i)$ and Clark Evans index (CEd). The permanent research plot with area of 2.5ha was established in National Naure Reserve Hrončecký grúň and subdivided into $25 \times 25 \mathrm{~m}$ subplots. The combination of mentioned indices was calculated for each subplot separately. Regarding the diameter heterogeneity, the most part of analyzed structures showed the moderate level of tree size differentiation ( $S$ - $W$ value $0.393 \pm 0.074)$. The presence of high number of juvenile individuals which already reached the diameter category "above $2 \mathrm{~cm}$ " did not significantly affect the diameter variation of investigated stand. On the other hand, a massive establishment of subsequent generation led to creation of spatial structure characteristic by high level of vertical differentiation (Gini coefficient 0.47 in the structure characterized as the breakdown with successive generation). High climax species richness was confirmed by calculated values of $D M i$ index (maximum relative presence in the category from 0.3 to 0.4). Each tree was surrounded by two and more different species individuals. Analysis discovers the negative developmental shift in the DMi values towards to less differentiated structures. Regarding the horizontal distribution the analysis of CEd values indicated that investigated natural forest can reveal a random distribution of individuals regardless of developmental stage.

Key words: spatial structure, nearest neighbor, natural forest, developmental shift

\section{Introduction}

In recent times, the biodiversity and protection of natural potential of forest ecosystems increase in importance. This phenomenon is notable in all human activities as well as in the forest management. A close-to-nature silviculture is oriented exclusively on management treatments mimicking processes of autoregulation and autoregeneration which are very well developed in condition of old-growth forests and are still driven by natural forces only (Korpel' 1995, Korpel', Saniga 1995). For this reason, the natural forest structure should to serve as a comparative frame for the decision making process in the landscape management and the main aim of the human intervention into commercial forest stands has to be the achieving such structure as well as possible.

It is very difficult to achieve the information about ecosystem functioning on the temporal scale, because the longevity of trees is much longer than the human is. Therefore the focus of forest researchers and practitioners should be oriented on the spatial aspect of forest structure.

Quantitative data on stand structure are essential inputs for understanding ecosystem structure and functioning, and hence for sustainable 
forest management (Kint et al. 2003). Spatial structure plays a crucial role in determination of the ecological diversity. The increasing structural heterogeneity, as a rule, is directly linked to a higher number of species as well as it results in a greater static stability (Pommerening 2002).

In the past, the focus of forest practices was concentrated on aspects of forest structure that were primarily required for timber management (Gadow, Bredenkamp 1992). As the continuous cover forestry has become a common term and environmental restrictions and guidelines increase, the forest activities started to be more oriented on the non productive outputs of forest ecosystems, e.g. soil and water protective function, recreational function and many others. Traditional measurement may no longer be sufficient (Graz 2004). The foresters are primarily oriented on the so called alpha and beta diversity (in the meaning of MacArthur 1965, Whittacker 1972). Inter stand diversity affects the growth and timer production, however moreover it directly controls variety of biotic and abiotic processes. It determines whole complex of microclimatic conditions, e.g. light patterns affecting the natural regeneration, litter composition or water balance (Kint et al. 2003, Pretzsch 2009).

Many new methods for quantifying the structural patterns and through this the biodiversity of forest stands has been developed. Many of them permit local and temporal comparison of horizontal and vertical construction of forest stands. There are two ways how to describe spatial structure of forest stand. The first is represented by simple mean value indices, which do not pay attention to the relative tree positions and are mostly used for quantifying of the horizontal and vertical heterogeneity. Neglecting the spatial variation within the stand can be regarded as the main disadvantage of this method. From among the plenty of non spatial indices, the most chosen is Shannon-Weaver index, often used for quantifying the species diversity. The second, more common way is to use the nearest neighbor indices, or so called spatial indices. Mentioned mathematical expressions take into account the relative position of each individual.

The proper combination of structural indices allows achieve detailed information about stand structure and can be regarded as the objective indicator suitable for mutual comparison of different forest structures. Many studies has been performed in order to describe spatial patterns by usage of structural indexes, from lowland Black alder stands (Bugala, Pittner 2010) to natural Norway spruce forests in the mountain zone (Kucbel et al. 2008, Kucbel 2012, Pittner, Saniga 2008). We were focused on the natural mixed forest located in $6^{\text {th }}$ forest vegetation zone for as much as it provides great variety of stand structures on the small area scale.

The main objective of this study is to describe spatial structure of mixed old-growth forest. Structural analysis will be presented in order to provide the reference data usable for practitioners to compare the commercial stand to natural structure and should set up the basis for human driven stand development.

Following aspects were analyzed in detail: 1) tree species diversity and mutual mixture of presented species, 2) vertical and horizontal differentiation was expressed by evaluation of tree diameter and height variability, 3) horizontal distribution of tree individuals.

All of the listed characteristics are calculated in spatial frame for the first, and in the frame of developmental change of forest structure in the second step.

\section{Materials and methods}

Regarding the orography, NNR Hrončecký Grún belongs to the Central Slovakia region, Pol'ana Mountains, and from the viewpoint of nature protection to the Biosphere Reserve Pol'ana Protected Landscape Area. Geographical coordinates of the area are $48^{\circ} 43^{\prime} \mathrm{N}$ and $19^{\circ} 35^{\prime}$ E. The originality and protection of the forest ecosystem in Hrončecký Grúň was already pointed up the forest management plan in 1934. There were no silvicultural operations carried due to its inaccessibility. This locality was later (year 1964) classified as a national nature reserve with the aim to protect of diverse old-growth forest communities.

Area of our interest is located in altitude 730 to $1050 \mathrm{~m}$ above sea level, average annual temperature $5.8{ }^{\circ} \mathrm{C}$, mean annual precipitation of $853 \mathrm{~mm}$, bedrock type andesite and migmatite, soil type cambisols and andosols. The tree species composition is created by seven climax species (Fagus sylvatica, L.; Fraxinus excelsior L.; Acer pseudoplatanus L; Acer platanoides L.; Ulmus glabra Mill. Picea abies L. Karst.; Abies alba Mill.). NNR Hrončecký Grúň, from the viewpoint of its reproductive characteristics and species composition, represents a unique ecosystem in European conditions. European ash, sycamore maple and wych elm reach there the top of their growth possibilities (Holeksa et al. 2009).

The field data collection was carried out on the permanent research plot (PRP) of $50 \times 500 \mathrm{~m}$, 
Tab. 1: Basic stand characteristics according to tree layers and tree species, PRP Hrončecký grún.

\begin{tabular}{|c|c|c|c|c|c|c|c|c|c|c|c|c|c|c|c|}
\hline \multirow{2}{*}{ 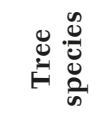 } & \multicolumn{5}{|c|}{ Upper layer } & \multicolumn{5}{|c|}{ Middle layer } & \multicolumn{5}{|c|}{ Lower layer } \\
\hline & $\mathbf{N}$ & DBH & $\mathbf{H}$ & G & $\mathbf{V}$ & $\mathbf{N}$ & DBH & $\mathbf{H}$ & G & $\mathbf{V}$ & $\mathbf{N}$ & DBH & $\mathbf{H}$ & G & $\mathbf{V}$ \\
\hline Beech & 52 & 51.3 & 39.5 & 11.6 & 242.6 & 42 & 27.5 & 25.0 & 2.7 & 34.2 & 210 & 4.0 & 4.4 & 0.5 & 1.7 \\
\hline Ash & 54 & 53.5 & 43.1 & 13.0 & 261.3 & 3 & 34.1 & 29.9 & 0.3 & 3.2 & 1 & 4.2 & 3.1 & 0.1 & 0 \\
\hline Maple & 21 & 41.9 & 36.6 & 3.1 & 57.8 & 12 & 30.9 & 26.9 & 1.0 & 13.8 & 8 & 4.6 & 4.0 & 0.1 & 0.1 \\
\hline Spruce & 36 & 61.8 & 44.0 & 11.6 & 214.3 & 5 & 25.1 & 22.8 & 0.3 & 2.5 & 0 & 0 & 0 & 0 & 0 \\
\hline Fir & 11 & 70.9 & 43.0 & 4.5 & 86.9 & 6 & 29.6 & 22.9 & 0.4 & 4.5 & 8 & 13.4 & 9.1 & 0.2 & 0.9 \\
\hline Others & 0 & 0 & 0 & 0 & 0 & 0 & 0 & 0 & 0 & 0 & 2 & 4.6 & 4.5 & 0.1 & 0.1 \\
\hline Total & 174 & 54.3 & 41.4 & 43.6 & 862.7 & 66 & 28.4 & 25.2 & 4.5 & 58 & 227 & 4.4 & 4.5 & 0.6 & 2.5 \\
\hline
\end{tabular}

Explanatory notes: $\mathrm{N}$ - number of individuals (pcs.ha $\left.{ }^{-1}\right)$; DBH - average diameter at the breast height (cm); $\mathrm{H}$ - average height of individuals (m); $\mathrm{G}$ - basal area $\left(\mathrm{m}^{2} \cdot \mathrm{ha}^{-1}\right) ; \mathrm{V}$ - volume of biomass $\left(\mathrm{m}^{3} \cdot \mathrm{ha}^{-1}\right)$ calculated according to Petráš, Pajtík (1991)

2.5 ha totally. The area of PRP was overlapped by $25 \times 25 \mathrm{~m}$ grid of subplots. The subplot represents a basic unit for subsequent detailed inventory.

\section{Data collection and analysis}

The position of each individual with $d b h \geq 2 \mathrm{~cm}$ was recorded in the coordinate system $\mathrm{x}, \mathrm{y}$ ( $N=1164$ individuals ). For each individual the following characteristics were determined (tree species, dbh, height $(h)$.

In order to obtain the detailed description of stand structure following structural characteristics were calculated for each subplot separately:

The diameter differentiation index (Td) (Kint 2003):

$$
T d=\frac{\sum_{j=1}^{n} 1-\frac{\min (d i, d j)}{\max (d i, d j)}}{n}
$$

Where: $d i$ - diameter of the $i^{\text {th }}$ central tree; $d j$ - diameter of the ${ }^{\text {th }}$ nearest neighbor of central tree; $n$ - number of neighbor trees

Calculated value reflects the variability in diameter in neighboring trees. Result values may vary within the range from 0 to 1 . For the purpose of results evaluation, the classification suggested by author has been used: $\mathrm{Ti} \leq 0.3$ - small differentiation, $0.3<\mathrm{Ti} \leq 0.5$ - moderate differentiation, $0.5<\mathrm{Ti} \leq 0.7$ high differentiation, $0.7<\mathrm{Ti} \leq 1$ very high diameter differentiation.

Vertical structure of investigated forest stand was described by Gini coefficient ( $G$ ) of height differentiation (Dixon et al. 1987).

$$
G=\frac{\sum_{1}^{n}(2 i-n-1) h i}{\sum h i(n-1)}
$$

Where: $h i$ - height value of $i^{\text {th }}$ individual, $n$ - number of individuals, $i$ - order of certain individual within the ascending sequence.

This index can take the values from 0 - all trees of investigated stand are of the same height, to theoretical 1 - all individuals are of zero height except the one individual of certain height. Classification of results was done in accordance to threshold values suggested by Kucbel (2006): $G i \geq 0,370$ vertically differentiated forest stands, $\mathrm{G} i \leq 0,270$ vertically leveled stands.

The positioning index (CEd) (Clark, Evans 1954) was chosen as a measure of spatial distribution of individuals. The calculated value can be regarded as a measure of the extent to which the observed population differs from random one in respect to horizontal distribution of individuals (Kint et al. 2003). During the calculation, we applied the edge effect correction according to Donelly (1978).

$$
C E d=\frac{\bar{r}_{s}}{\bar{r}_{t}}=\frac{\frac{\sum_{i=1}^{N} r_{i}}{N}}{0,5 \sqrt{\frac{A}{N}+0,051368 \frac{P}{N}}+0,041 \frac{P}{\sqrt[2]{N^{3}}}}
$$

Where: $r_{i}$ - distance between tree $i$ and its nearest neighbor, $N$ is the total number of trees in investigated stand, $A$ is the area of the investigated plot, $P$ is the perimeter of investigated plot. 
Calculated values are from interval of theoretical minimum - 0 (all trees are clumped into a single point) to theoretical maximum - 2.1491 (regular hexagonal distribution). The value 1 represents the ideal random distribution.

In order to test the calculated values against a significant deviation of 1 , we applied the $T$ statistic.

$$
T=\frac{\overline{r_{s}}-\bar{r}_{t}}{\sqrt{0,0703 \frac{A}{N^{2}}+0,037 P \sqrt{\frac{A}{N^{5}}}}}
$$

Species diversity of the stand was determined by calculating the Shannon-Weaver index (S-W) (Weaver, Shannon 1949):

$$
H^{\prime}\left(p_{1}, p_{2}, \ldots, p_{n}\right)=-\sum_{j=1}^{n} p_{j} \ln \left(p_{j}\right)
$$

Where: $p j$ - probability, that a randomly chosen tree is of the $j$ species, $n$-number of tree species occurring in the stand

The index can take the values from 0 (only one species occurs) to theoretical maximum $H_{\max }=\ln S$, all occurring species are represented by the same number of individuals (for our case, we calculate with 5 climax species: $H_{\max }=\ln 5=$ $=1,609$ ).

Relative position of certain tree species in investigated stands was calculated using Mixture index (DMi) of von Gadow (1999).

$$
D M_{i}=\frac{1}{3} \sum_{j=1}^{3} V_{i j}
$$

Where: $v_{i j}-$ is 1 , if the tree is of another species, or 0 , if the tree is of the same species; $n$ - number of neighbor considered; $i$ - denotes the sample tree evaluated.

Calculated value can reach only four values: 0 - all neighbors are of the same species, 0.33 one neighbor is of another species, 0.66 - two of the neighbors are of another species and 1 - all of the neighbors are of another species. Simple arithmetic mean represents the average index value for the stand and is of the interval $0 \leq D M_{i} \leq 1$. Low values of index imply that trees of certain species are grouped, while values close to 1 indicate the mingling of co-occurring tree species.

Structural indices were calculated using software BwinPRO 5.0 ( $\mathrm{Td}$ index, DMi index, CEd index, Shannon-Weaver index) and Tstrat 3.0 software (Gini coefficient). Statistical evaluation of calculated values was performed in STATISTICA 7.0 software.

In accordance to analyze of developmental change in the index distribution, each subplot was classified into one of tree structural types. The structural types follow the temporal changes chaused by natural dieback of individuals as well as the autoregeneration processes. Following types of structure were recognized: Optimum structure $(\mathrm{O})$ - represents the mature stand with the closed canopy. Mature individuals are standing in upper tree layer, the middle and lower layer could be occupied by shade-tolerant tree species. Breakdown structure (B) - is characterized by openings in the canopy caused by natural dieback of mature trees. There is lack of biologically secured natural regeneration (DBH above $2 \mathrm{~cm}$ ). Breakdown structure with subsequent generation (Bsg) - opened canopy, lower layer is occupied by massive occurrence of subsequent generation of climax species.

\section{Results}

Following chapter compares spatial structure on the set of 40 subplots. As well as the structural diversity of permanent research plot was evaluated, we focused on the change of forest structure along the temporal scale. Three types of structure (optimum structure, breakdown structure and breakdown structure with successive generation) which occurs within the frame of developmental cycle of natural forest were confronted by statistical methods.

Diameter differentiation of natural forest structure in investigated stand is presented on Fig.l (right). The average value of Füldner index was $0.393 \pm 0.074$ and it varied from 0.237 to 0.568 . It is clearly visible, that most of the index values ranged from 0.3 to 0.5 . The most part of subplots showed moderate level of diameter differentiation. The analysis of variance did not confirm ( $p$-level 0.156) the differences in diameter differentiation between evaluated structures (Fig. 1 right). We can recognize highest level of differentiation in the breakdown structure and the lowest in the breakdown structure with subsequent generation.

Vertical differentiation of investigated stand is described in the Fig. 2. The average Gini index value was $0.257 \pm 0.128$. The distribution of index values shows significant left sided asymmetry with maximum frequency in the range from 0.1 to 0.2 . From this point we can recognize the descending trend in index values towards the recorded maximum value of Gini coefficient 0.632 . Occurrence of juvenile individuals 

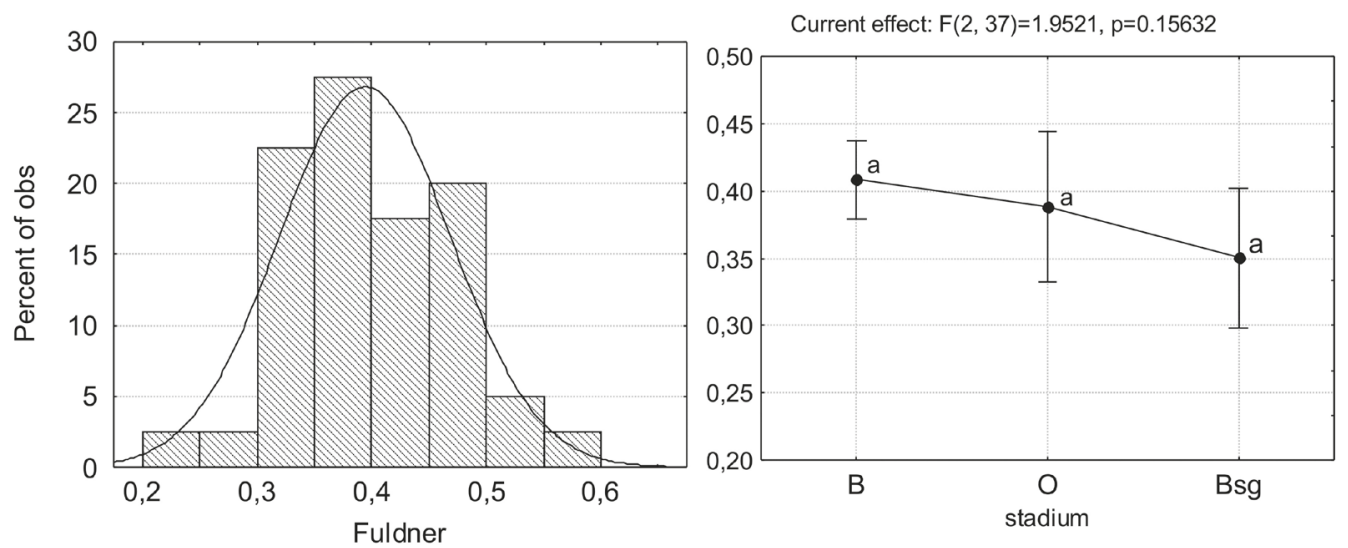

Fig. 1: Distribution of diameter differentiation index (Td) values (left) and developmental shift of index values (right) in the PRP Hrončecký grún (Vertical lines denote $95 \%$ confidence interval).
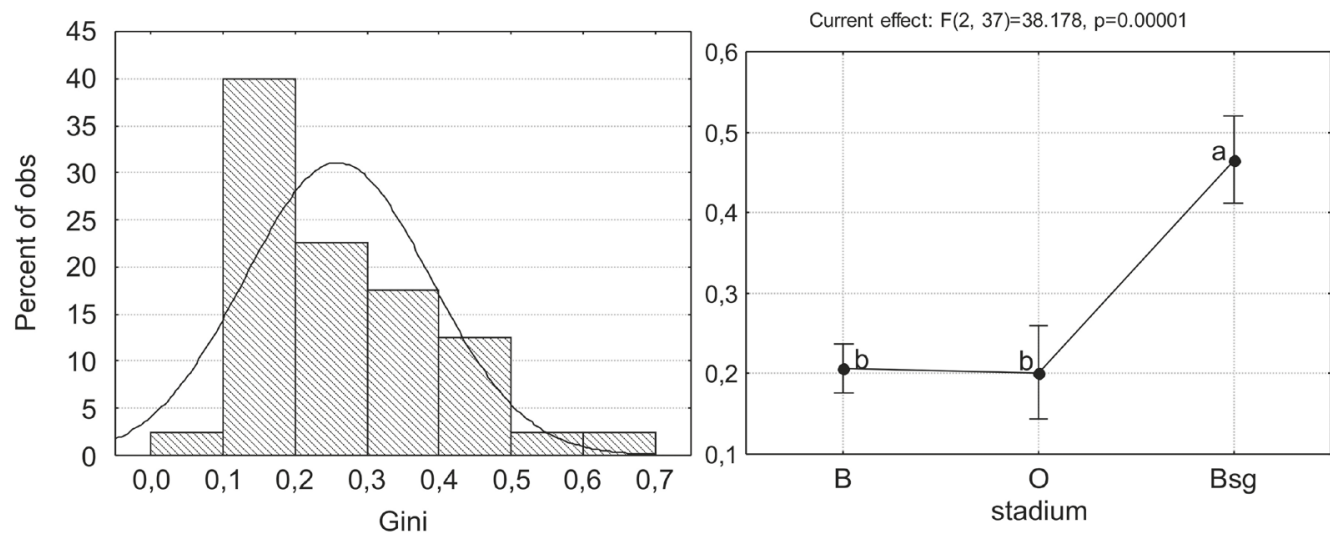

Fig. 2: Distribution of Gini index (G) values (left) and developmental shift of index values (right) in the PRP Hrončecký grún (Vertical lines denote $95 \%$ confidence interval).

resulted in statistically significant $(p=0.00001)$ increase of vertical differentiation (Fig. 2 right). Analysis of variance did not confirm the significant change in height differentiation between the optimum structure and the breakdown structure. According to classification scheme these structures can be characterized as a vertically leveled. Overall developmental shift could be described as a continuous change from vertically leveled structures towards to highly differentiated stands.

Tree species composition of investigated forest stand was determined using the combination of distance independent Shannon-Weaver index and nearest-neighbor mingling index. In the Fig. 3, the distribution of S-W values is presented. Right sided asymmetry distribution revealed the maximum relative occurrence in the range from 1.2 to 1.4. Minimum recorded value of S-W index was 0.208 , however cases with lower species differentiation were rather sparse, up to $15 \%$. The average calculated value $1.05 \pm 0.309$ points to rather high level of the species heterogeneity with distinctive equal proportion of all species in the stand structure. When the developmental shift in tree species composition was analyzed it can be recognized statistically significant decrease in S-W values. The breakdown structure revealed the variation of S-W values at the level of approximately $60 \%$ of the average calculated value (0.663).

Similar situation has been observed during the analysis of tree species mingling. The evaluation of DMi values distribution showed the similar pattern as the S-W values did. Left sided distribution is characterized by maximum relative 

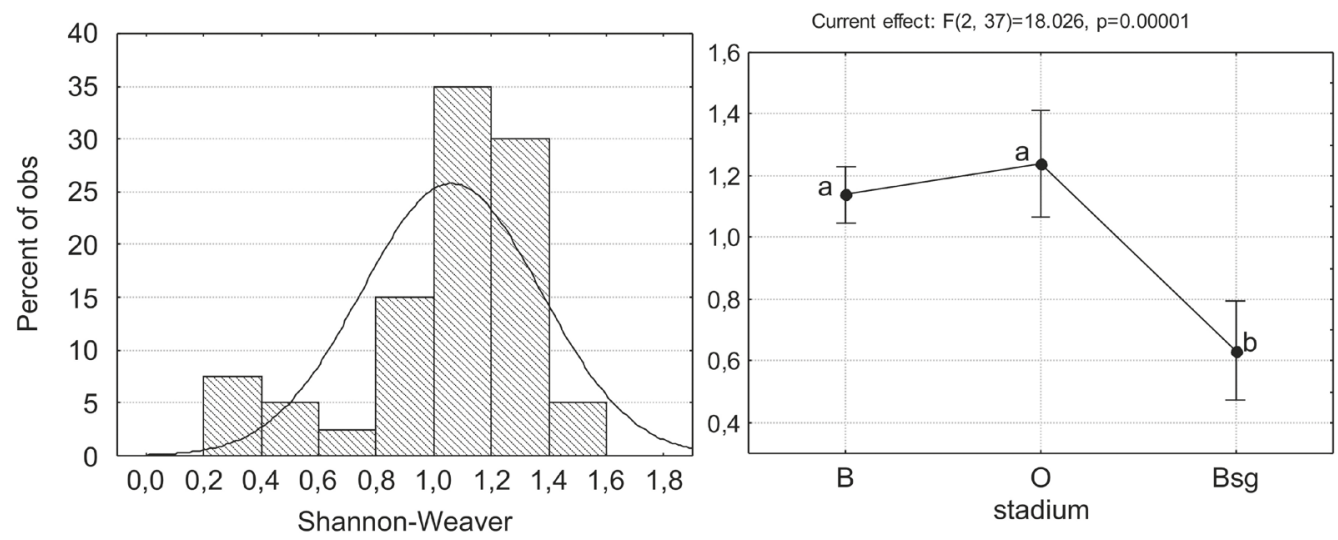

Fig. 3: Distribution of Shannon-Weaver index (S-W) (left) and developmental shift of values (right) in the PRP Hrončecký grún (Vertical lines denote $95 \%$ confidence interval).
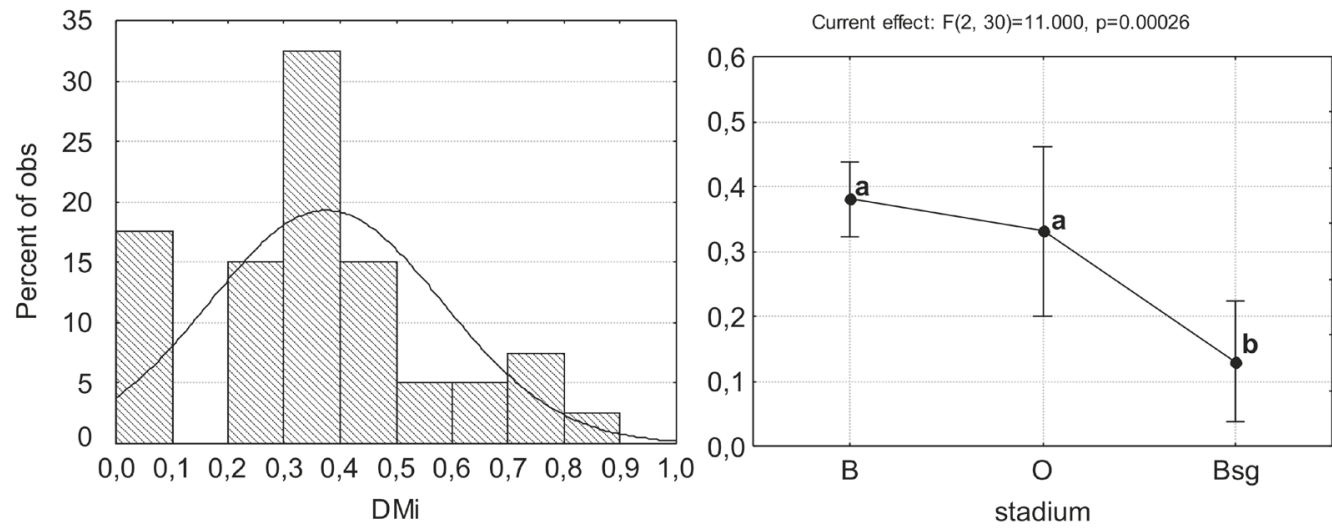

Fig. 4: Distribution of mingling index (DMi) values (left) and developmental shift of values (right) in the PRP Hrončecký grún (Verticallines denote $95 \%$ confidence interval).

presence in the category from 0.3 to 0.4 and the lack of DMi values in the range from 0.1 to 0.2. According to classification scheme and calculated values, the most part of structures showed high level of tree species heterogeneity, where the every individual had been surrounded by at least two trees of the different species. Temporal shift of the tree species mingling resulted in gentle increase of DMi value in breakdown structure and was followed by sudden decrease at the level of 0.137 in Bsg structure (Fig. 4 right).

Horizontal distribution of trees on investigated plot was quantified by calculation of CEd index. The CEd value had been estimated for each subplot separately. The distribution of values among the whole permanent research plot is demonstrated on the Fig. 5 (left). The variation interval is characterized by minimum achieved value 0.818 and maximum value of 1.049 . However, the subsequent testing of $\mathrm{T}$ characteristic confirms the significant deviation of calculated values against 1 only in five cases (subplots). According to mentioned fact, complex structure of investigated plot can be characterized by random horizontal distribution of tree individuals.

\section{Discussion}

All analyzed structural characteristic must be discussed with respect to the natural origin of investigated stand. The tree species richness as well as the mixture of tree species with different tolerance to shade has resulted into the higher level of spatial diversity in comparison with the managed forests. 

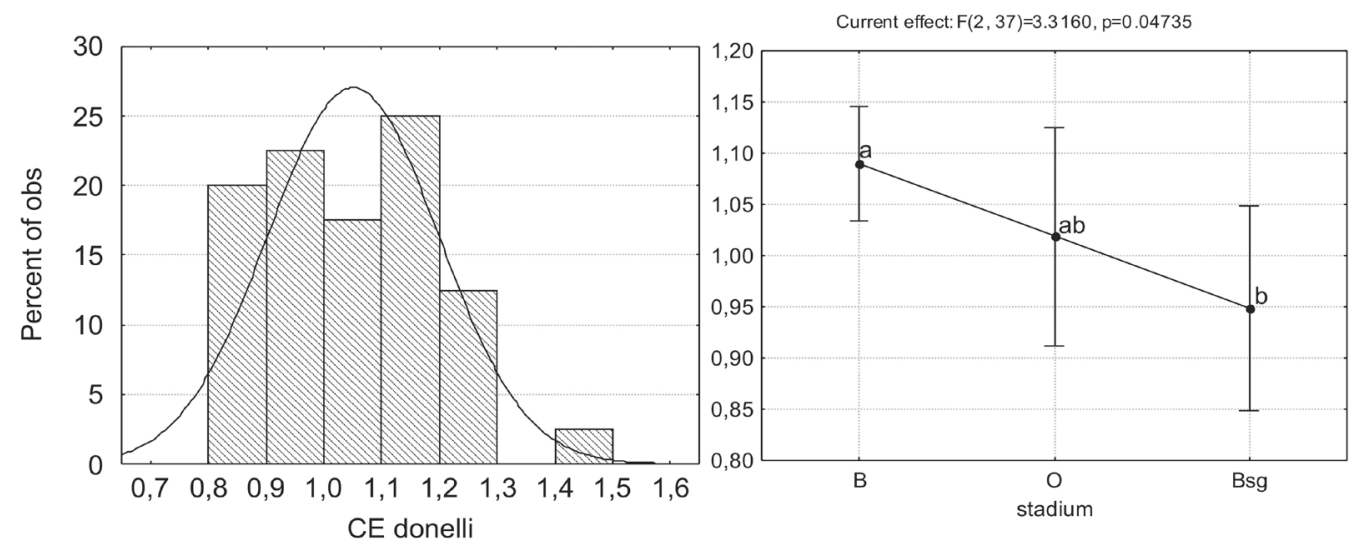

Fig. 5: Distribution of CEd values (left) and developmental shift of CEd values (right) in the PRP Hrončecký grún̆ (Vertical lines denote $95 \%$ confidence interval).

Regarding the diameter heterogeneity, the most part of analyzed structures (86\% of subplots) showed the moderate level of tree size differentiation. Such fact is definitely linked to natural character of the analyzed stand, while the size differentiation processes are driven exclusively by natural competition and age-related dieback of mature individuals. In the initial phase of the breakdown, the natural mortality of canopy individuals caused the slight increase in size differentiation. As the rule, the mortality of mature trees is followed by establishment of natural regeneration. The presence of high number of juvenile individuals which already reached the diameter category "above $2 \mathrm{~cm}$ " did not significantly affect the diameter variation of investigated stand.

On the other hand, massive establishment of subsequent generation led to creation of spatial structure characteristic by very high level of vertical differentiation. When comparing overall structure of natural forests to managed forest stands, the higher level of size differentiation can be stated. Szmyt (2012) analyzed the spatial structure of managed beech dominated forest stands under different type of silvicultural treatments. Author stated rather low structural diversity in term of DBH and tree height variation. We confirmed that either the natural forest rich in tree species is able to achieve such a homogenous, vertically leveled structure, especially in the stage of optimum, however this structure is not sustainable for a longer period. Kucbel, Saniga (2012) dealt with the analysis of present state of the structure in a mixed fir-beech forest stand that was left for the natural development without any human impact 25 years ago. Their results confirmed that relatively homogenous stand structures with the dominance of beech and fir from upper tree layer are still prevailing in the stand. The most common type (70\%) was the less differentiated structure with sparsely emerging lower tree layer. In the same NNR as analyzed by Kucbel, Saniga (2012), Vencurik et al. (2012) observed more or less differentiated structures on the $40 \%$ of the stand area what confirmed the successive and spontaneous tendency towards the age, diameter and height differentiation of mentioned stand. As far as the tree species representation in the structure and developmental cycle is evaluated, in the case of the old-growth forest Hrončecký Grún̆, the analysis confirmed rather high level of species heterogeneity. Such structure is typical for natural forests occurring on the very diverse bedrock from the point of view of lithological patterns. Site conditions make this natural forest stand out among others occurring in middle Europe (Holeksa et al. 2009).

High climax species richness was confirmed by calculated values of DMi index as well. Each tree was surrounded by two and more individuals of the different species. Analysis discovers the negative developmental shift in the DMi values towards to less differentiated structures. The successive generation is almost exclusively composed by beech individuals what cause the significant decrease of species heterogeneity. Beech as a very competitive tree species is able to supress the establishment of samplings of other species. Mentioned process was described by Saniga et al. (2011). Authors regarded the change in tree species composition as to be a naturally driven cyclic process sustainable only under present conditions (high attack of browsers, small-scale disturbances). Strong dominance 
of beech in term of mingling with other stand constituents has been observed by high number of authors (e.g. Bilek et al. 2011, Gadow, Hui 2007). Pommerening (2002) confirmed the same patterns in the old-growth oak-beech forests, where oaks were surrounded by at least 3 beech individuals.

Regarding the horizontal distribution presented CE values indicated that natural forest can reveal a random distribution of individuals regardless of developmental stage. If we suppose that main factor influencing the spatial structure of natural forest is the random mortality, such process lead to random positioning of trees. Within the structural frame of natural forest, the regular positioning could occur only in larger groups of young individuals, where the competition is the main factor influencing spatial organization (Szmyt 2012).

\section{Conclusion}

The paper provides the complex overview on structural patterns of the natural mixed species forest in natural nature reserve Hrončecký grúň. The nearest neighbor approach was applied to describe relations among tree individuals. This method pays special attention to the spatial position of individuals what shoul be very important for forest ecology studies. If compared to the classic forestry inventory (diameter distribution, volume calculation, height curve etc.) it allows the more objective comparison of different forest stands.

\section{References}

Bilek, L., Remes, J., Zahradnik, D. 2011: Managed vs. unmanaged. structure of beech forest stands (Fagus sylvatica L.) afetr 50 years of development, Central Bohemia. Forest Systems, 20: 122-138.

Bugala, M., Pittner, J. 2010: Analýza štrukturálnej diverzity porastov jelše lepkavej (Alnus glutinosa (L.) Gaertn.) na území VŠLP TU vo Zvolene. [The analysis of structural diversity of the Black alder stands located in the Forest enterprise TU Zvolen]. Acta Facultatis Forestalis Zvolen, 52 (1): 43-54.

Clark, P.J., Evans, F.C. 1954: Distance to nearest neighbour as a measure of spatian relationship in populations. Ecology, 35: 445-453.

Dixon, P.M., Weiner, J., Mitchell-Olds, T., Woodley, R. 1987: Bootstrapping the
However, the main disadvantage of the used method could be the noticeable time cost of data collection (especially tree position recording). The mentioned problem can be significantly eliminated by using modern devices (e.g. FieldMAP ${ }^{\circledast}$, GPS positioning) during the data collection.

Analysis of spatial structure confirmed the high level of structural diversity. Observation of spatial pattern of natural forests and the application of achieved information into silvicultural treatments should the main way how to secure the high level of static stability and sustainable management of forest ecosystems. Obtained knowledge could be used for projection of appropriate tree species composition in forest restoration or management of protected areas. It allows formation of more stable forest structures that should be more resistant to impact of biotic and abiotic factors in the future.

\section{Acknowledgement}

I would like to thank my colleagues who provided a helping hand during the field work as well as help me with their valuable advice during the manuscript preparation: Prof. Milan Saniga, Dr. Ján Pittner, Dr. Stanislav Kucbel, Ján Hronec, Peter Imre and many others.

\section{Funding}

This study was supported by Slovak Science Agency VEGA project No 1/0381/12.

Gini Coefficient of Inequality. Ecology, 68: 1548-1551.

Donnelly K.P. 1978: Simulation to determine the variance anded ge effect of total nearestneighbour distances. In: HodDER, I. (ed.) Simulation methods in archeology. Cambridge Press, London, 91-95.

GADOw, K. 1999: Waldstruktur und Diversität. Allgemeine Forst und Jagdzeitung., 170: 117-122.

Gadow, K., BredenKamp, B. 1992: Forest management. Academica, Pretoria, 151 pp.

Gadow, K., HuI, G.Y. 2007: Characterizing forest spatial structure and diversity. Forestry Studies, 46: 13-22.

GrAz, F.P. 2004: The behaviour of the species mingling Msp in relation to species dominance and dispersion. European Journal of Forest Research, 123: 87-92. 
Holeksa, J., Saniga, M., Szwagrzyk, J., Czerniak, M., StaszyńsKa, K., Kapusta, P. 2009: A giant tree stand in the Western Carpathians - An exception or a relic formerly widespread mountain European forests? Forest Ecology and Management, 257: 1577-1585.

KINT, V. 2003: Structural development in ageing Scots pine (Pinus sylvestris L) stands in Western Europe. PhD thesis. Ghent University. 194 pp.

Kint, V., van Meirvenne, M., Nachtergale, L., Geudens, G., Lust, N. 2003: Spatial methods for quantifying forest standstructure developmnent: a compariuson between nearestneighbor indices and variogram analysis. Forest Science, 49: 36-49.

Korped, Š. 1995: Die Urwalder der Westkarpaten. Gustav Fischer Verlag, Stuttgart, Germany. 310 pp.

Korpel, Š., SAniga, M. 1995: Prírode blízke pestovanie lesa. [Close to nature silviculture]. LF TU, Zvolen. 159 s.

Kucbel, S. 2006: Štruktúra porastov a optimalizácia pestovných opatrení vo vysokohorských lesoch v oblasti Nízkych Tatier. [Stand structure and the optimalisation of silvicultural treatments performed in mountain forests of the Low Tatra Mts.] PhD. thesis. TU Zvolen. 108 s.

KuCBEL, S. 2011: Štruktúra porastov a regeneračné procesy vo vysokohorských ochrannýchlesoch Nízkych Tatier. [Stand structure and regeneration processes of the mountain forests in Low Tatras Mts.]. TU Zvolen. 138 s.

Kucbel, S., SAniga, M. 2012: Variabilita porastových štruktúr zmiešaného lesa v NPR Mláčik. [Stand structure variability of the mixed species forest in NNR Mláčik]. In: Saniga, M., Kucbel, S., Jaloviar, P. (eds.): Pestovanie lesa v strednej Európe, TU vo Zvolene, 60-68.

Kucbel, S., Vencurik, J., Jaloviar, P., Kuriš, P. 2008: Analýza štruktúry vo vysokohorskom ochrannom lese Nízkych Tatier. [Structure analysis of the mountain protec- tion forest in Low Tatras Mts.] Acta facultatis forestalis Zvolen, 50 (2): 57-65.

MacArthur, R.H. 1965: Pattern in species diversity. Biological Reviews, 40: 510-533.

Petráš, R., РAjtík, J. 1991: Sústava československých objemových tabuliek dreva. [The Czechoslovakian tree volume tables]. Lesnícky časopis, 37: 49-56.

PitTner, J. 2008: Štrukturálna diverzita a ekologická stabilita smrekového prírodného lesa v doline Nefcerka. [Structural diversity and ecological stability of the Norway spruce natural forest in the Nefcerka valey]. PhD. thesis. TU Zvolen. 124 s.

Pittner, J., Saniga, M. 2008: A change in structural diversity and regeneration processes of the spruce virgin forest in Nefcerka NNR (TANAP). Journal of Forest Science, 54 (12): 545-553.

Pommerening, A. 2002: Approaches to quantifying forest structures. Forestry, 75: 305-324.

Pretzsch, H. 2009: Forest dynamics, growth and yield. Springer-Verlag, Berlin, 664 pp.

Saniga, M., Balanda, M., Kucbel, S., Jaloviar, P., 2011b: Cyclic changes in tree species composition of mixed-species forest in western Carpathians: role of disturbance and tree regeneration. Polish Journal of Ecology, 59 (4): 609-708.

SzMYT, J. 2012: Spatial structure of managed beech-dominated forest: applicability of nearest neighbor indices. Dendrobiology, 68: 69-76.

Vencurik, J., Kucbel, S., Jaloviar, P., 2012: Typizácia porastových štruktúr a analýza stavu prirodzenej obnovy zmiešaného lesa v Národnej prírodnej rezervácii Mláčik. [Standardization of the stand structures and analysis of natural regeneration in the mixed natural forest NNR Mláčik]. Zprávy lesnického výzkumu, 57: 93-100.

Weaver, W., Shannon, C. E. 1949: The Mathematical Theory of Communication. Urbana, Illinois.

WHITTAKER, R. H. 1972: Evolution and measurement of species diversity. Taxon, 21: 213-251. 